\title{
多翼送風機の羽根車およびスクロール形状の 軸方向変化が性能と騒音に及ぼす影響*
}

\author{
山崎 進*1, 橋 本 克 彦*2, 深 作 良 範*3

\section{Influence of Shape Change of Impeller and Scroll in the Axial Direction on Performance and Noise for Multiblade Blower}

\author{
Susumu YAMAZAKI, Katsuhiko HASHIMOTO and Yoshinori FUKASAKU
}

\begin{abstract}
In this paper, the influence of shape change of the impeller and scroll in the axial direction on performance and noise are investigated. It is shown that a $14 \%$ increase in the hub-side diameter of the impeller over that of the shroud side leads to a $4 \%$ increase in the efficiency $\eta_{t}$ and a $2 \mathrm{~dB}$ reduction in the specific sound level SLs. It is also shown that an increase in the diffusion angle of the hub side of the scroll to that of the shroud side raises the efficiency by $2 \%$.
\end{abstract}

Key Words: Fluid Machinery, Velocity Distribution, Aerodynamic Performance, Aerodynamic Acoustics, Multiblade Blower

\section{1. 緒言}

多翼送風機の内部流れは, 主流が主板に傾斜して流 れること，また側板側と主板側で流速差が大きいこと， さらに羽根出口の流速が非軸対称であること, など複 雑な三次元流れをしており，これが多翼送風機の低効 率, 高騒音の主因になっている(1) (8). 本報告は, 多翼 送風機の高効率化と低騒音化を目的に，まず送風機の 内部流れを測定して流動状態を検討し，次に羽根車お よびスクロールの形状を流れに合せて軸方向に変形さ せた場合の空力性能と騒音への影響を検討している。

\section{2. 記 号}

$$
\begin{aligned}
b & : \text { 羽根幅 } \mathrm{mm}, \mathrm{m} \\
\Delta b & : \text { 流扎がブロックしている領域の羽根幅 } \mathrm{mm} \\
c & : \text { 絶対流速 } \mathrm{m} / \mathrm{s} \\
D & : \text { 羽根径 } \mathrm{mm}, \mathrm{m}
\end{aligned}
$$

* 原稿受付 1996 年 12 月 10 日.

*1 正員, (株) 日立製作所機械研究所（正300土浦市神立町 502).

*2 (株) 日立製作所自動車機器事業部（正 101-10 東京都千代田 区神田駿河台 4-6)

*3 (株) 日立製作所自動車機器事業部（３12 Uたちなか市高 場 2520).

$$
\begin{aligned}
& i \text { : 入射角 。 } \\
& L: \text { 軸動力 } \mathrm{W} \\
& p_{s}: \text { 静圧 } \mathrm{Pa} \\
& p_{t}: \text { 全圧 } \mathrm{Pa} \\
& Q \text { : 風量 } \mathrm{m}^{3} / \mathrm{s} \\
& \mathrm{SL} \text { ：騒音レベル(吸込口 } 1 \mathrm{~m} \text { ) } \mathrm{dB} \\
& \mathrm{SLs} \text { ：比騒音レベル } \mathrm{dB} \\
& =\mathrm{SL}-10 \log \left[60 Q\left(P_{t} / \rho\right)^{2}\right] \\
& u \text { : 羽根風速 } \mathrm{m} / \mathrm{s} \\
& W: \text { スクロール幅 } \mathrm{mm} \\
& x: \text { 羽根幅方向の座標 } \\
& \alpha: \text { 流出角 。 } \\
& \beta_{\infty} \text { : 羽根設計角度 。 } \\
& \beta: \text { 流れ角度 } \\
& \delta \text { ：回転軸に対する流れの傾き角 } \\
& =\tan ^{-1}\left(c_{m} / c_{x}\right) \text { 。 } \\
& \rho: \text { 密度 } \mathrm{kg} / \mathrm{m}^{3} \\
& \eta_{t}: \text { 全圧効率 \% } \\
& \lambda \text { : 動力係数 }=L /(\rho / 2) \pi D_{2} b_{2} u_{2}^{3} \\
& \psi \text { : 圧力係数 }=p /(\rho / 2) u_{2}^{2} \\
& \phi: \text { 流量係数 }=Q / \pi D_{2} b_{2} u_{2} \\
& \text { 添 字 }
\end{aligned}
$$

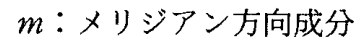




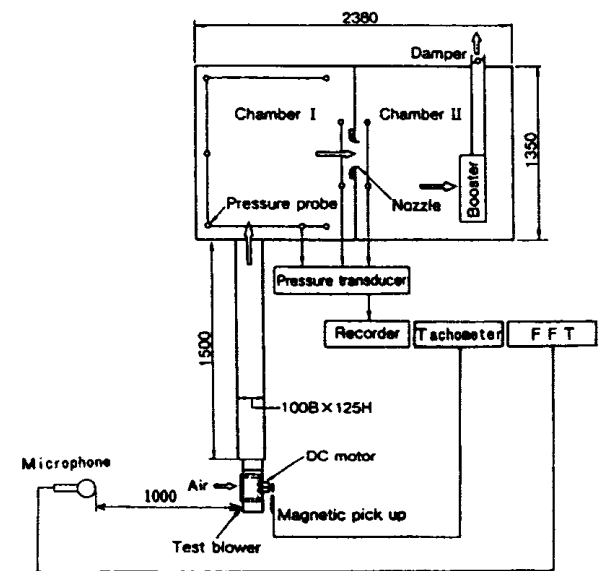

Fig. 1 Schematic of experimental apparatus

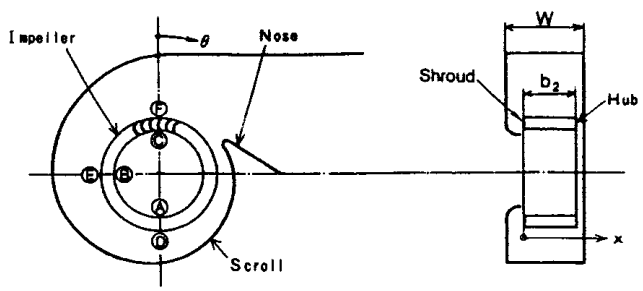

(a) Inspection points

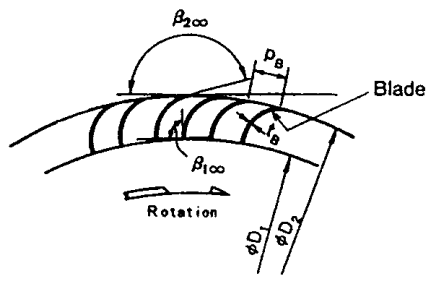

(b) Shape of blade

Fig. 2 Inspection points

$u$ : 周方向成分

1：羽根内径の位置

$2:$ 羽根外径の位置

\section{3. 実験装置および実験方法}

本実験に用いた供試羽構車(No.1) は外径 $D_{2}$ が 140 $\mathrm{mm}$, 内径 $D_{1}$ が $120 \mathrm{~mm}$, 羽根幅 $b_{2}$ は $57 \mathrm{~mm}$, 羽根 出口角 $\beta_{200}$ は $175^{\circ}$, 羽根入口角 $\beta_{100}$ は $90^{\circ}$, 羽根数が 43 枚のプラスチック製であり，スクロールは $84 \mathrm{~mm}$ の等幅対数らせんの形状である。

図 1 は，実験装置の概略図である、装置は JISに基 づく装置で，二つのチャンバ間に取付けたノズルによ り精度よく流量を測定する方式であり，流量が比較的 小さい場合の測定に適した流量, 圧力測定装置であ る. 騷音はスクロールの吸込口で, 正面 $1 \mathrm{~m}$ の位置で 測定している。供試羽根車の軸動力は小さいのでトル ク計を使わずに淔流モータに直結し，モータ出力を軸

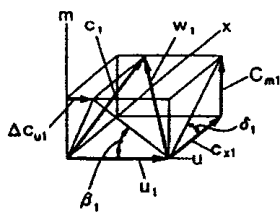

(a) Inlet

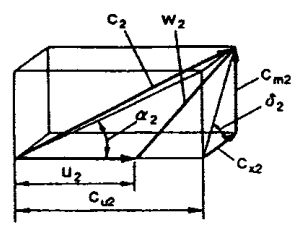

(b) Outlet
Fig. 3 Velocity diagram

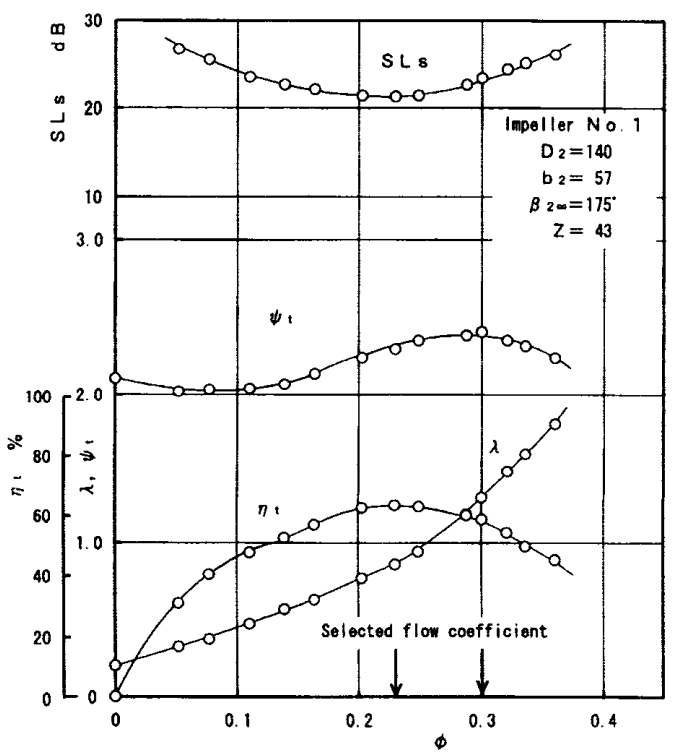

Fig. 4 Aerodynamic performance of testing blower

動力として計算した。モータ特性は, あらかじめモー 夕の入力電压, 電流, 回転数, 周囲空気温度とモー夕 出力との関係を実験的に詳細に測定した. 供試羽根車 は電圧を調整して $2500 \mathrm{rpm}$ の一定速度で回転させて いる.

図 2 は, 供試送風機の内部流れを調べるための測定 点および供試羽根車の形状因子を示す，測定点は羽根 車入口 (点 $A \sim C$ ), 羽根車出口 (点 $D \sim F)$ の 6 筒所で

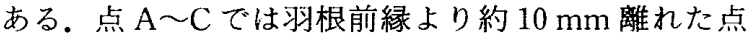
を，点 $\mathrm{D} \sim \mathrm{F} て ゙ は$ 羽根外周より $3 \mathrm{~mm}$ 離れた点におい て、五孔ピトー管 (直径 $6 \mathrm{~mm}$ )を軸方向にトラバース している。

図 3 は, 羽根入口, 羽根出口の流速と流れ角度の記 号を示す. 図 3(a), (b) とも, 絶対速度は $c$, 径方向 流速成分は $c_{m}$, 円周方向流速成分は $c_{u}$ としている.

\section{4. 実験結果および考察}

$4 \cdot 1$ 内部流れの検討図 4 は, 本研究で使用し た多翼送風機の空力性能を示す。本研究では内部流れ を検討する作動点として，サージングなどの不安定な 状態がなく，また全压効率が最高効率に近く，工業上 


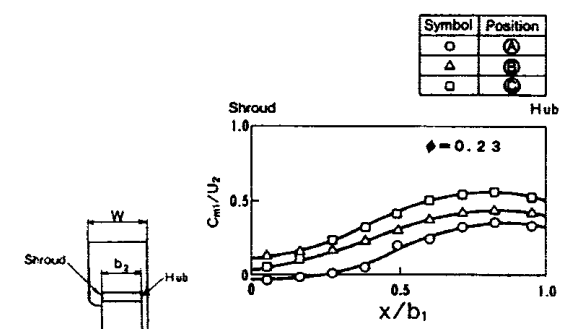

(a) Meridian velocity

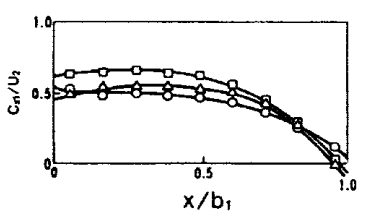

(b) Axial velocity

Fig. 5 Velocity distribution at inlet of blade

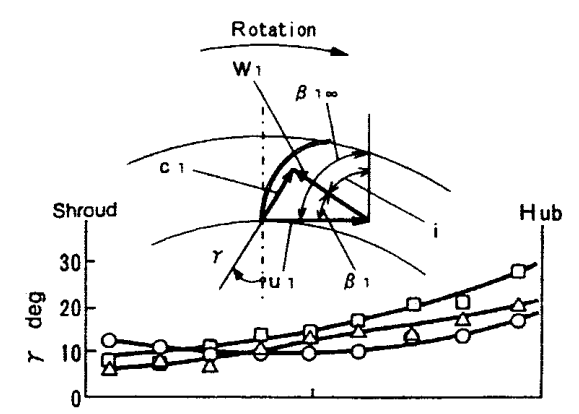

(a) Inlet angle

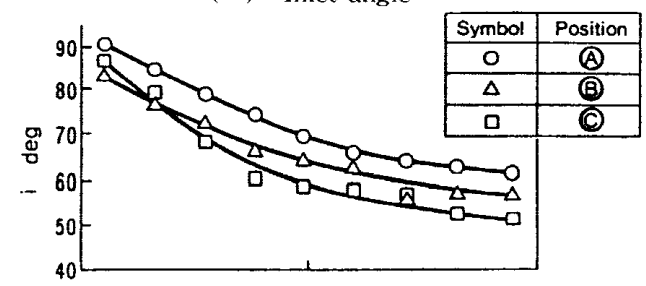

(b) Incidence angle

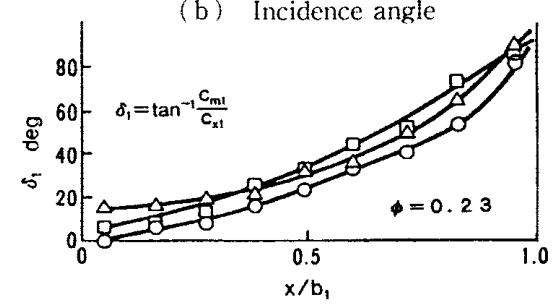

(c) Incline angle

Fig. 6 Angle of flow at inlet of blade

の設計点として採用されている流量で行うこととし， 流量係数 $\phi$ が 0.23 の流量を選んだ.

図 5 は, No. 1 羽根車入口における半径方向流速成 分 $c_{m 1} / u_{2}$ と軸方向流速成分 $c_{x 1} / u_{2}$ を示寸. 流れの分 布は側板付近では $c_{x 1}$ が大きくて $c_{m 1}$ が小さく, 主板 に近づくにつれ流れは主板に沿って流れるので $C_{x 1}$ が

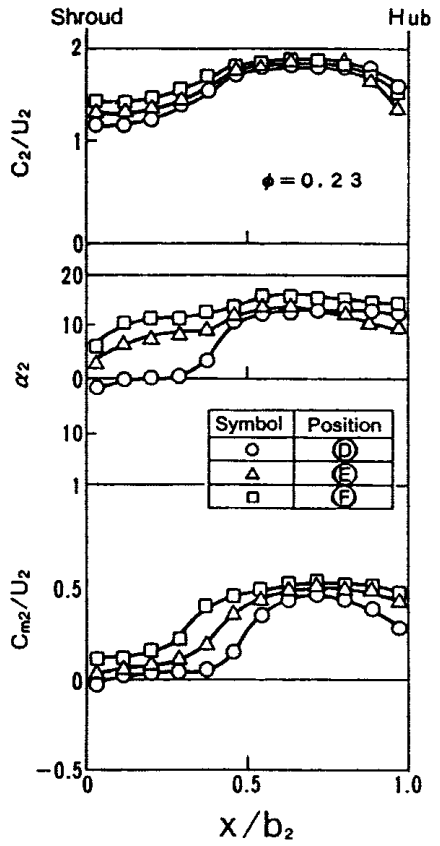

Fig. 7 Velocity distribution of outlet of blade

小さく $c_{m 1}$ が大きくなる， $c_{m 1}$ の大きさを円周方向で

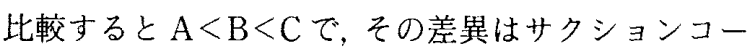
ンの面よりさらに大きくなる，側板付近の $c_{m 1}$ が小さ い領域 $\left(\Delta b\right.$, 軸方向ブロッケージ(1) は, 羽根幅 $b_{1}$ の $35 \%$ 占めている。．また，図 6 は羽根車入口側におけ る流入角 $\gamma$, 入射角 $i\left(=\beta_{1 \infty}-\beta_{1}\right)$ と軸方向傾斜角 $\hat{o}_{1}$

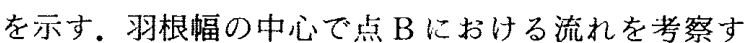
ると, 軸方向傾斜角 $\delta_{1}$ は $32^{\circ}$ で主板側に大きく傾斜 して扔り，またこの点の羽根入口の入射角は $65^{\circ}$ で大 きく, 羽根背面側に大きなはく離の発生が予測され た。一方, 羽根幅全体では側板付近は $i$ が大きく $\gamma$ と ठが小さく，主板に近づくにつ机て $\gamma$ と $\hat{o}_{1}$ が大きく なる。

眓7は，羽根車出口における流速分有を示す。全般 に絶対流速の比 $c_{2} / u_{2}$ は約 1.5 であり, 流出角 $\alpha_{2}$ は $0 \sim 15^{\circ}$ でほほ接線方向に流出している. 半径方向成 分 $c_{m 2} / u_{2}$ の軸方向分布は, 側板側が小さく主板側が 大きいが, $c_{m 2}$ の主板側への偏向の傾向は羽根入口の 場合よりさらに增し，軸方向ブロッケージは羽根偪 $b_{2}$ の $40 \%$ 占めている. 円周方向の $c_{m 2}$ の分布を見る と, $c_{m 2}$ の大きさは $\mathrm{D}<\mathrm{E}<\mathrm{F}$ で羽根入口と同じ順序 であり, 点 $\mathrm{F} の$ 流量 $\int_{0}^{b_{2}} c_{m 2} d x$ の值は点 D の約 1.6 倍である. 流れの傾斜角 $\delta_{2}$ は, 妆根幅の中心の位置 $\left(x=0.5 b_{2}\right)$ で $79^{\circ}$ ，主板に近い位置 $\left(x=0.75 b_{2}\right)$ で $84^{\circ}$ である。

$4 \cdot 2$ 傾斜羽根車の検討 図 8 は, 羽根径が軸方 向に平行な羽根車 (No. 1) と傾斜羽根車(No.2)のおの 


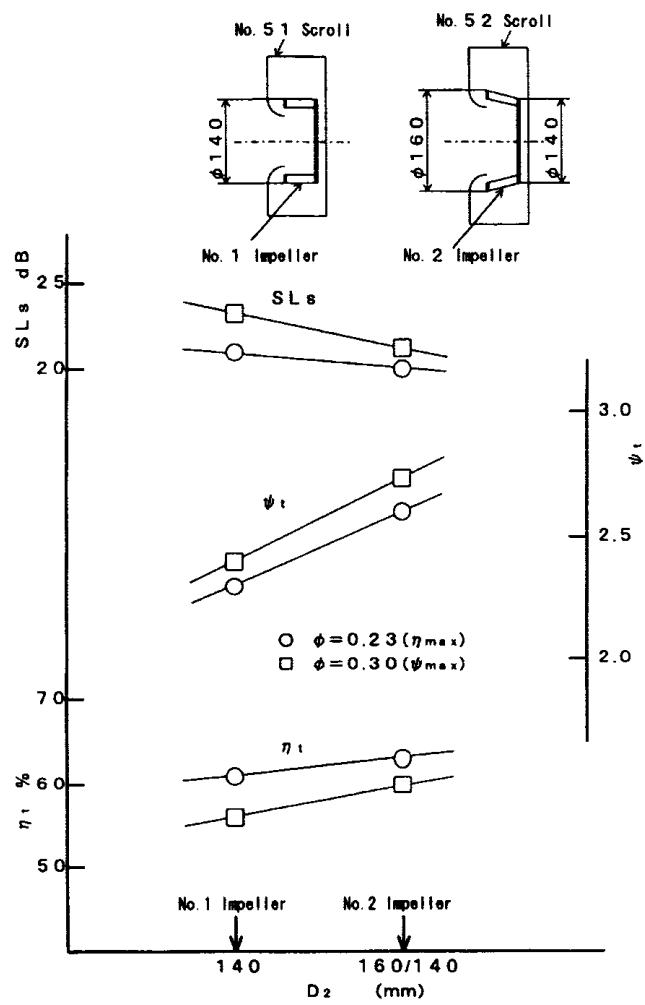

Fig. 8 Effect of Inclined Imperller

おののファン性能で, ○印は流量係数 $\phi$ が 0.23 の場 合, 口印は $\phi$ が 0.30 の場合である。 $\phi$ が 0.23 の点は No. 1 羽根車の場合に全圧効率 $\eta_{t}$ が最大の流量であ り, $\phi$ が 0.30 の点はNo. 1 羽根車の場合に圧力係数 $\phi_{t}$ が最大の流量である. 傾斜羽根車(No.2)の $\phi_{t}$ の 計算における周速 $u_{2}$ として, 側板側周度 $(20.9 \mathrm{~m} / \mathrm{s})$ と主板側周速 $(18.3 \mathrm{~m} / \mathrm{s})$ の算術平均值 $(19.6 \mathrm{~m} / \mathrm{s})$ を 使用している。

図 8 の No. 51 スクロールは羽根径として $140 \mathrm{~mm}$, 抎大角が $5.3^{\circ}$ のスクロール，またNo. 52 スクロール は $160 \mathrm{~mm}, 5.3^{\circ}$ で羽根径が大きい分だけスクロール も大きいので, 両者の性能の比較は, 全圧効率 $\eta_{t}$ と比 騒音レベル SLs で比較した。全般に傾斜羽根車のほ うが平行羽根車より $\eta_{t}$, SLs のいずれにおいても優 れ，特に大流量域ほど $\eta_{t}, \mathrm{SLs} の$ 差が大きい. $\phi$ が 0.30 の場合 (口印), 傾斜羽根車は平行羽根車より $\eta_{t}$ は 4\%, SLsは $2 \mathrm{~dB}$ おのおの改善される。

図 9 は, 平行羽根車および傾斜羽根車の同一流量に お ける羽根出口の流速分布を示す. 傾斜羽根車の場 合, 平行羽根車に比べ側板側の羽根径が大きいため絶 対速度の比 $c_{2} / \boldsymbol{u}_{2}$ は約 7\%大きくなが, 半径方向成 分 $c_{m 2} / u_{2}$ は逆に約 $12 \%$ 小さくなる. 流出角 $\alpha_{2}$ の大き さは傾斜羽根車のほうが若干小さくなる，図 9 より， 傾斜羽根車の $c_{m 2} / u_{2}$ の軸方向分布は, 平行羽根車に 比べ，若干軸方向に均一化の傾向が表れている.

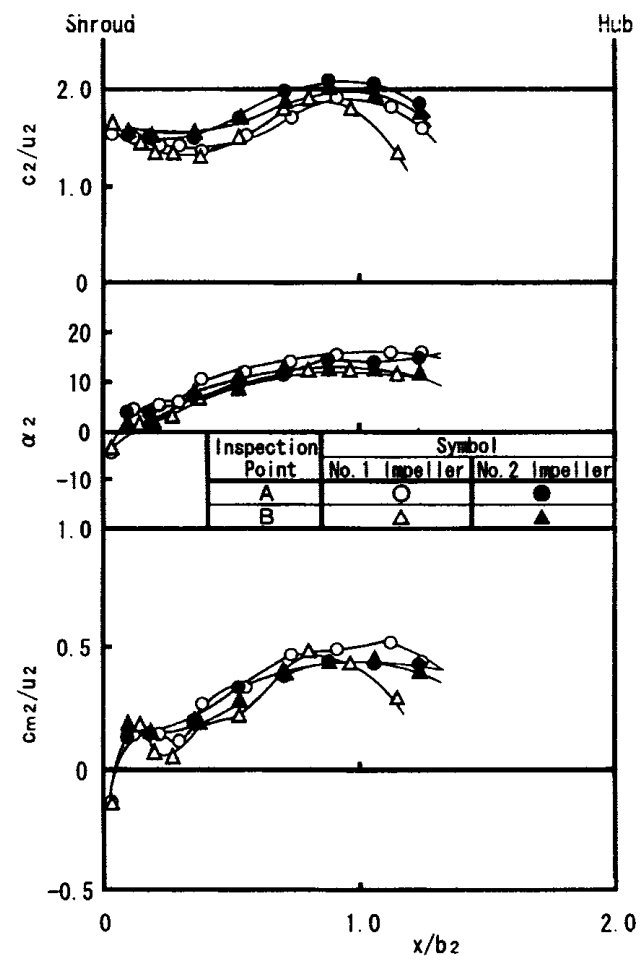

Fig. 9 Velocity distribution of outlet of inclined blade
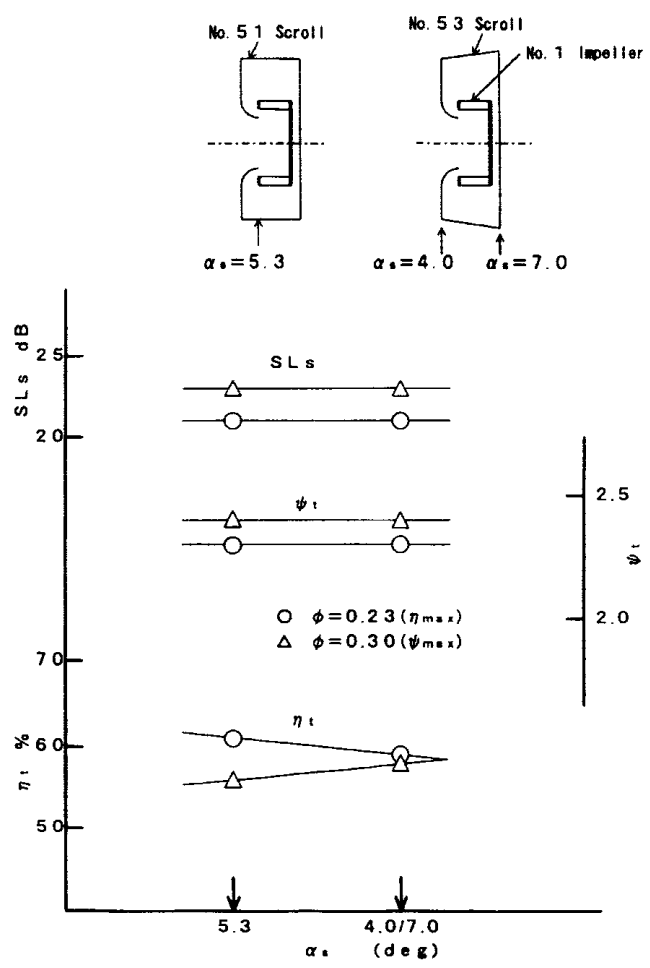

Fig. 10 Effect of Inclined Scroll

本研究では, 羽根径の傾斜化により, 流速 $c_{2}, c_{m 2}$ の軸方向均一化を目標にしたが, 今回のデータでは流 速の片寄りの均一化の効果は小さかった。これは，羽 
根径の軸方向のこう配 $\left.\left[=\tan ^{-1}\left(D_{2 S}-D_{2 H}\right) / 2 B\right)\right]$ が $8^{\circ}$ で小さく,この程度のこう配では側板側の羽根の仕 事量の増加が小さいためと考えられる。

$4 \cdot 3$ 傾斜スクロールの検討 図 10 は,スクロー ルの背板が軸方向に平行な場合 (No.51) と背板を軸方 向に傾斜させた場合(No.53)のおのおののファン性能 である．主板側の径方向流速 $c_{m 2}$ が側板側より大きい ので, 傾斜スクロールは $C_{m 2}$ の傾向と同様にスクロー

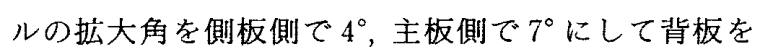
傾斜させ， $\phi_{t}, \eta_{t}$ の向上を目的としている.図 10 上 り, 傾斜スクロールは平行スクロールに比べ, $\eta_{t}$ は全

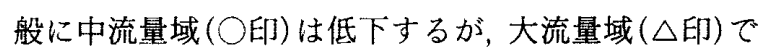
は逆に向上し， $\phi$ が 0.30 の場合 ( $\triangle$ 印), 傾斜羽根車の ほうが平行羽根車より $2 \%$ 向上する.一方，比騒音レ ベルは，傾斜羽根車と平行羽根車は全流量域でほほ同 じである.上述の図 9 より, 羽根車内の主流は主板側 へ傾いており，傾斜スクロールは主板側の拡大角を大 きくしているので, 特に大流量域の動压の静圧への変 換が十分に行われたためと考えられる。

\section{5. 結言}

（1）羽根車の入口では主流は回転軸に対し $4 \sim 20^{\circ}$ で主板側に傾斜して流れ, 軸方向ブロッケージ は，羽根入口では羽根幅全体の35\%，また出口では
40\%を占めている.

（2）側板側の羽根径を主板側より14\%大きくす ると, 径方向流速成分の軸方向均一化が促進し, 全圧 効率が $4 \%$ ，比騒音レベルが $2 \mathrm{~dB}$ 向上する.

(3) 主板側のスクロール拡大角を側板側より大き くすると, 大流量域での動圧の静压への変換がスムー スに行われ，全圧効率が $2 \%$ 向上する.

\section{文献}

（1）山崎進・佐藤良次，多翼送風機の空力性能に関する研究 (第 1 報), 機論, 52-484, B (1986), 3987-3992.

（2）山崎進・佐藤良次, 多䝨送風機の回転羽根車内の流れ，流 れの可視化, 7-7(1987)，425-430.

(3) Raj, D. and Swim, B., Measurements of Mean Flow Velocity and Velocity Fluctuations at Exit of Cent lifugal Fan Rotor, Trans. ASME, J. Eng. for Power, (1981), 393-399.

（4）山本勝・川檽正昭・ほか2名, 多翼ファン翼間流れの流 速分布可視化計測，ターポ機械，23-10(1995)，604-609.

（5）門田茂・川口清司・ほか 2 名, 多翼ファン低騒音化の研 究(第 1 報), 機論, 60-570, B (1994)，452-457.

（6）川门清司・門田茂・ほか2名, 多翼ファン低騷音化の研 究 (第 2 報)，機論，60-570，B(1994)，458-463.

（7）近藤泰司・浅野秀夫，カーエアコン用低騒音シロッコフ アンの開発，自動車技術講演全論文集，No.941(1995)， 145-148.

（8）山崎進・佐藤良次・ほか 1 名, 多翼送風機の空力性能に 関する研究(第 3 報)，機論, 53-490，B(1987)，1730-1735. 